\title{
Drivers of abrupt and gradual changes in agricultural systems in Chad
}

\author{
Erik Nilsson $^{1}$ (D) $\cdot$ Per Becker $^{2,3} \cdot$ Cintia Bertacchi Uvo ${ }^{1}$
}

Received: 24 April 2019 / Accepted: 26 May 2020 / Published online: 16 June 2020

(C) The Author(s) 2020

\begin{abstract}
The countries in the Sahel are undergoing rapid changes due to a mixture of demographic, ecological, and economic transformations. Rural livelihoods in these countries are predominantly engaged in agriculture, which is a foundational component of both food security and the general economy. The relationships between ongoing socio-economic transformation and the agricultural sector are clearly important to address poverty and sustainable development, but have received little academic attention on a subnational level of analysis. This paper addresses this by bringing together new datasets on demography, international aid, food security reports, and soil moisture to analyze the drivers of change in the agricultural sector on a subnational level in Chad. Both regression analyses and qualitative methods based on descriptions in food security reports are used to evaluate the relationships between these datasets to agricultural statistics for the period 1990-2016. It finds that changes to crop water availability from rainfall largely are decoupled from the long-term increases in crop production. On the other hand, it shows that population changes and international aid can explain differences in long-term agricultural changes between Chad's regions. Moreover, stochastic factors such as farm support programs, market prices, access to new markets, and accommodation of refugees are identified as important to grasp abrupt changes in the crop production. Beyond the specific findings for Chad, this study presents a framework for improved evaluation of the drivers behind subnational crop production on multi-annual and decadal time scales, with broad applicability to agricultural systems in the Sahel.
\end{abstract}

Keywords Agricultural production · Population · International aid $\cdot$ Livelihood analysis $\cdot$ Soil moisture $\cdot$ Sahel

\section{Introduction}

Agricultural production in countries in the Sahel has undergone substantial changes over the past three decades (FAO 2018a; FAO and AfDB 2015). While this has been reported

Communicated by Chinwe Ifejika Speranza

Electronic supplementary material The online version of this article (https://doi.org/10.1007/s10113-020-01668-9) contains supplementary material, which is available to authorized users.

Erik Nilsson

erik.nilsson@tvrl.lth.se

1 Division of Water Resources Engineering, Lund University, P.O. Box 118, S.E-221 00 Lund, Sweden

2 Division of Risk Management and Societal Safety, Lund University, Lund, Sweden

3 Unit for Environmental Sciences and Management, North-West University, Potchefstroom, South Africa on the national level for a number of countries (FAO and AfDB 2015), a detailed understanding of the drivers of these changes is generally lacking (Fuglie and Rada 2013). Although a range of generic drivers commonly are proposed, such as population increase, technological change, weather patterns, terms of trade, agricultural research and investments, and public policies, they have not been established with sufficient precision to be used for evaluative and predictive purposes (Binswanger-Mkhize and McCalla 2010; FAO and AfDB 2015; IMF 2015). This poses direct limitations for food security management in the short-term as well as for long-term strategies and programs for rural development. A key issue behind this is that the analytical environment is complicated, mainly due to the fact that a large ratio of the population is involved in the agricultural sector, under conditions of rapid demographic and socio-economic changes, and with generally low institutional capacities (FAO and AfDB 2015).

Added to this, both monitoring and evaluation require detailed and extensive dataset. While the use of panel datasets are enabled by occasional surveys of the rural sector (e.g., 
Houssou and Chapoto 2014; Josephson et al. 2014), data that track the evolution of agricultural systems over time are generally limited to the national scale (e.g., Binswanger-Mkhize and McCalla 2010; FAO and AfDB 2015; Fuglie and Rada 2013; Nin Pratt 2015). Several ongoing monitoring initiatives across the Sahel are now addressing this lack of spatial detail (CILSS 2018; FAO 2018b, 2016; FEWS NET 2018a; Food Security Cluster 2018; Traore et al. 2014). Despite this increasing data availability, attributing drivers to agricultural changes is often confined to statistical analysis on national levels (e.g., Bachewe et al. 2015; Epule and Bryant 2015) or qualitative assessments in specific areas (e.g., Nin-Pratt and McBride 2014; Ouedraogo et al. 2015; Ouédraogo et al. 2017; Snorek et al. 2014; Valbuena et al. 2015; Wood et al. 2014), while methodological and spatial combinations of the two are rare (e.g., Abro et al. 2014; Muyanga and Jayne 2014; Wood et al. 2014). Also, due to the multitude of actors involved in data collection, with various agendas, comprehensive research methods that combine the existing datasets are needed to establish more precise relationships in agricultural dynamics in the Sahel.

The purpose of this study is to improve the understanding of changes in agricultural systems on subnational levels in the Sahel and advance the associated methods. The study is based on a set of case examples from Chad, where the effects of demographic variables, international aid, food security reports, and soil moisture on long-term changes in subnational cereal production for 1990-2016 are assessed. The focus is on the differences in production trajectories between the administrative regions in Chad over this time period, and complements a recent study (Nilsson et al. 2019) which addressed the drivers of interannual variability in crop production for the same areas and time period. Due to the general lack of previous studies with this focus, and as most of the employed datasets have not been combined on a regional level of analysis in Chad before, assessing their combined explanatory capacity is of relevance for evaluative and predictive purposes in the agricultural sector. It further serves to identify improvements needed to advance the precision of the results and the applicability of the developed methods across the Sahel.

\section{Agricultural systems in Chad}

The patterns of change in regional agricultural production in Chad have been analyzed by Nilsson and Uvo (2018), who found that $83 \%$ of the increases in production for the period 1990-2016 can be explained by expansions in harvested area. They also emphasized the importance of distinguishing between abrupt and gradual changes in the agricultural production over this time period, as they found that $80 \%$ of the increase in harvested area and $89 \%$ of the increase in yield in the Sahelian zone in $\mathrm{Chad}^{1}$ were due to abrupt changes, i.e., changes occurring at a single year with a statistically detectable lasting effect (see "Agriculture" section). For the Soudanian zone, the corresponding rates due to abrupt changes were $81 \%$ for harvested area and $80 \%$ for yield. The analysis employed in this study builds directly on their results, to identify potential causes behind the various abrupt and gradual changes behind the long-term production trajectories.

Chad has among the highest population growth and urbanization rate in the world (World Bank 2018a). With agriculture being the most common occupation in the country (INSEED et al. 2016), demographic changes are likely to affect agricultural production. Migration is a key feature in demographic change, and is likely to differ considerably between regions, considering different employment opportunities, security threats, and family connections. Nilsson and Uvo (2018) compared growth rates in total and agricultural population to growth in agricultural output for regions in the Sahelian and Soudanian zones in Chad, and found evidence of linear relationships, indicating that both the harvested areas and the yields grow partly in response to population driven demand and labor availability in the respective regions.

How these and other demographic factors affect the agricultural sector in different areas are however largely dependent on development programs and public investments, which in turn are linked to security problems in neighboring countries, dependence on volatile oil revenues, and inefficient public financial management (IMF 2013; World Bank 2014). Moreover, the effects of public investments are not systematically monitored and evaluated due to the complexity of the agricultural sector, low data availability, and limited operational resources (IFAD 2011; World Bank 2014). However, public spending in the agricultural sector has increased more than the sector's contribution to GDP, indicating a prioritization of agricultural development from the government (World Bank 2014), which is also displayed through recent strategies and development programs (Ministry of Agriculture and Irrigation 2013; République du Tchad 2017; 2014; 2003). Furthermore, public investments are directly dependent on international aid, which is estimated to cover three quarters of the public capital expenditures (World Bank 2014). At the same time, similar issues of uncertain impact evaluations as for the public sector persists in the international aid sector (Herdt 2010; IRAM-ADE 2016), which is further complicated by the multitude of actors involved.

Finally, there are pronounced interannual variabilities in the agricultural sector, which despite their fundamental

\footnotetext{
${ }^{1}$ Note that "the Sahelian zone" and "the Soudanian zone" refer to groups of regions in Chad, while "the Sahel" refers to the ecological zone covering several countries.
} 
influence on food security generally are not well understood (Nilsson et al. 2019). Due to dry growing conditions across the ecological zones in Chad, high ratio of rainfed farming, and varying hydrological conditions, soil water availability is bound to be a key factor behind these interannual variabilities (FEWS NET 2011; Nilsson et al. 2019; Republic of Chad 2009). While this warrants an evaluation of the role of soil water availability in long-term changes to agricultural output, the substantial increase in agricultural output seen in all regions in Chad over the past three decades indicate a strong influence of anthropogenic drivers (Nilsson and Uvo 2018).

\section{Methodology}

\section{Data}

Data were collected to cover the main potential environmental and socio-economic drivers of agricultural change on a regional scale in Chad, under the current data availability conditions. While crop water availability was included, data on other biophysical aspects such as soil fertility and local differences in crop varieties were not acquired. Availability of data on socio-economic aspects of relevance for agricultural production in Chad is generally low, and a data review resulted in the selection of demographic census data, international aid as reported from international aid organizations, and monthly food security reports from FEWSNET. Table 1 presents an overview of the datasets used in this study.

\section{Agriculture}

The agricultural statistics were acquired from the Chadian government agencies Direction de la Production et des Statistique Agricoles (DPSA) and the Institut National de la Statistique, des Études Économiques et Démographiques (INSEED), and are described in detail in Nilsson and Uvo (2018). They cover the harvested area, yield, and production of cereal crops for 1990-2016 for each administrative region in Chad. As the purpose of this paper was to study the drivers of the long-term trends and changes in the agricultural sector, estimates of the trend levels in the agricultural variables for each year were needed. Due to the high interannual variability in the agricultural statistics, as well as the presence of abrupt changes (Nilsson and Uvo 2018), the trend levels were estimated by using the abrupt changes identified in Nilsson and Uvo (2018) combined with 5-year moving averages between points of abrupt changes. These abrupt changes were in Nilsson and Uvo (2018) defined as points in the time series with significant Wald scores, as calculated by the Wald test for structural change in linear regressions (Andrews 1993). The Wald test compares the differences in linear regressions coefficients and variances between subsamples, and its application on this dataset is described in Nilsson and Uvo (2018). Gradual changes in turn refer to long-term changes over a given period, without considering whether changes are due to abrupt changes or not. Five-year moving averages were opted for over linear trends as estimates of the trend levels between abrupt changes to be more sensitive to interannual

Table 1 Overview of datasets

\begin{tabular}{|c|c|c|c|c|}
\hline Variable & Definition & Time & $\begin{array}{l}\text { Sample rate } \\
(\%)\end{array}$ & Source \\
\hline $\begin{array}{l}\text { Agricultural } \\
\text { statistics }\end{array}$ & $\begin{array}{l}\text { Annual production, harvested area, and yield for all } \\
\text { cereal crops for each administrative region in Chad }\end{array}$ & 1990-2016 & - & $\begin{array}{l}\text { (DPSA 2017; see Nilsson and Uvo } 2018 \text { for full } \\
\text { description) }\end{array}$ \\
\hline $\begin{array}{l}\text { Yield reduction } \\
\text { factors }\end{array}$ & $\begin{array}{l}\text { Estimated effect from daily soil water availability } \\
\left(0.1^{\circ} \text { spatial resolution }\right) \text { and crop water uptake on } \\
\text { crop yield }\end{array}$ & 1990-2016 & - & (see Nilsson et al. 2019) \\
\hline Total population & - & 1993, 2009 & 100,100 & (INSEED 2012, 1993) \\
\hline $\begin{array}{l}\text { Agricultural } \\
\text { population }\end{array}$ & $\begin{array}{l}\text { Main occupation during the } 12 \text { months preceding the } \\
\text { survey }\end{array}$ & $\begin{array}{l}1993,2009 \\
2014\end{array}$ & $100,100,9$ & (INSEED 2012, 1993; INSEED et al. 2016) \\
\hline Poor population & $\begin{array}{l}\text { Member of household with income below set annual } \\
\text { poverty threshold }\end{array}$ & 2003, 2013 & 5,15 & (INSEED 2006; WFP 2013) \\
\hline $\begin{array}{l}\text { Literate } \\
\quad \text { population }\end{array}$ & $\begin{array}{l}\text { Individual with the ability to read or write a simple } \\
\text { phrase in any language }\end{array}$ & 1993, 2009 & 100,100 & (INSEED 2012, 1993) \\
\hline Mean income & Mean income per household & 2003, 2011 & 5,11 & (INSEED 2013, 2006) \\
\hline $\begin{array}{l}\text { Income } \\
\text { inequality }\end{array}$ & Rate of highest to lowest household income quintile & 2003, 2011 & 5,11 & (INSEED 2013, 2006) \\
\hline International aid & Aid project descriptions, duration, and amount of aid & 1990-2016 & - & $\begin{array}{l}\text { (Mainly IATI 2018a \& IATI 2018b; see } \\
\text { Appendix for full list) }\end{array}$ \\
\hline $\begin{array}{l}\text { Livelihood } \\
\text { information }\end{array}$ & $\begin{array}{l}\text { Information from monthly food security reports on, } \\
\text { e.g., food availability, conflicts, market prices, } \\
\text { population movements, and pests }\end{array}$ & 1990-2016 & - & $\begin{array}{l}\text { (FEWS NET 2018b; see Nilsson et al. } 2019 \\
\text { for full description) }\end{array}$ \\
\hline
\end{tabular}


variabilities, to be able to compare differences in trend levels over short evaluation periods. To enable a comparison between regions with large differences in population and initial production values, the growth rates over the periods of interests were used. As each region produces various type of cereals crops (FEWS NET 2011), regional aggregates were created for total harvested area, average yield, and total production for each year. All crop outputs within a region were thus treated equally in their importance for local livelihoods.

\section{Soil moisture}

To estimate the effect of changes in soil water availability, yield reduction factors based on rainfall, soil water holding capacity, wind conditions, evaporative demand, and crop water uptake were calculated for the respective regions and crops (Allen et al. 1998; Doorenbos and Kassam 1979; Steduto et al. 2012). This study used the yield reduction factors in Chad described and calculated by Nilsson et al. (2019), who analyzed the role of crop water availability to the interannual variability in crop production for the same areas and time period that this study covers. The effects of changes in soil water availability on the agricultural trend level $\left(\Delta A g r_{\text {soil water }}\right)$ at a specified year, $t$, were estimated according to Eq. (1). As these estimates of soil water driven yield reductions only covered the rainy seasons, hydrological dynamics related to flood recession farming were not included.

$$
\begin{aligned}
& \Delta A g r_{\text {soil water }}=A g r_{t, \text { trend }} \times\left(\frac{Y_{\_} r e d_{t}-Y_{\_} r e d_{\text {start }}}{Y \_r e d_{\text {start }}}\right) \\
& \Delta A g r_{\text {soil water }}=\text { Effect from soil water availability on agricultural trend level at year } t \\
& A g r_{t, \text { trend }}=\text { Agricultural trend level at year } t \\
& Y \_r e d_{t}=\text { yield reduction factor at year } t(\%)
\end{aligned}
$$

Start $=$ mean value for initial years in sample, $t=1 \rightarrow 3$

\section{Demographic data}

The demographic data stem from the only two nationwide demographic censuses conducted in Chad, in 1993 and 2009 (INSEED 2012; 1993), complemented with surveys on consumption and the informal sector in 2003 and 2011 (INSEED 2013; 2006), rural food security in 2013 (WFP 2013), and rural occupations and livelihoods in 2014 (INSEED and ICF International 2016) (Table 1). The generally low sample rates and sparse temporal distribution of these datasets limit their utility for this study. Instead, only broad comparisons can be made between the regions and specific points in time.

\section{International aid data}

Data on international aid were mainly taken from the International Aid Transparency Initiative (IATI) datastore (IATI 2018a) and its explorer of geocoded data, d-portal (IATI 2018b). As reporting to IATI is voluntary, several donor organizations hold more detailed and extensive project information in their respective project databases. For the main donor organizations, the IATI data were thus complemented with donor specific project databases (see Appendix). AidData also provides geocoded data from selected donor organizations, which in the case of Chad only is available for the World Bank and the Global Environment Facility (Goodman et al. 2016). In total, 4451 international aid projects were identified for the period 1990-2016. To evaluate the effect of international aid on regional agricultural variables, data were extracted from each project on: project period, project budget, target location, aid category according to OECD's Development Assistance Committee (DAC) (OECD 2018) and project descriptions. All project budgets were converted to US dollars and deflated to 2016 price levels by using the Consumer Price Index (World Bank 2018b). For projects with no disbursement data available, the project budget was set to the committed amounts and distributed equally over the full project period on an annual level. Three-digit DAC5 sector categories were used (OECD 2018a), which gave sufficient detail to be able to distinguish between the main types of international aid, and enabled a categorization of projects based on their project descriptions if DAC categories were not given. Both loan and grant components were included, as loan repayment periods often are extended over long periods, and as funds for loan repayments were expected to be drawn from other DAC sectors than the target sector.

Besides the general difficulty of impact evaluations for development projects in Chad (IFAD 2011; IRAM-ADE 2016), the main limitation with the international aid data is that the target location often is imprecise or lacking from project entries. For the majority of projects in Chad not included in AidData or d-portal, project locations were ascribed to specific regions in Chad by using a search algorithm that compared texts in the project titles and project descriptions to location names in Chad. A comprehensive list of location names were built from a list of all cities in Chad (MaxMind 2018), all districts and regions (INSEED 2008), refugee camps from UNHCR and FEWSNET reports (e.g., FEWS NET 2015; UNHCR 2018a), and general location (e.g., North Chad, Northern Chad) in English and French. Target locations were then ascribed to regions according to the location names identified in the project texts. As Chad is receiving large amounts of international aid directed to humanitarian projects for refugees, target locations for project texts mentioning refugees without any location names were ascribed according to the location of refugees in Chad for the project 
period. The number and location of refugees for each year were estimated based on UNHCR's population statistics (UNHCR 2018b), based on their country of origin and the regions hosting each refugee population. Project budgets for such entries were then split over all regions hosting refugees, weighted according to the estimated number of refugees in each region.

To evaluate the effect of international aid on the agricultural sector, a set of four aid groups covering different DAC categories were created (Aid group 1= Agriculture, forestry, fishing; Aid group 2 = Aid group $1+$ Emergency response + Water supply \& sanitation; Aid group $3=$ Aid group $2+$ General environmental protection + Transport \& storage + Education + Health + Other social infrastructure \& services; Aid group $4=$ All 14 DAC categories). The aid groups were created to have a decreasing direct focus on the agricultural sector, which is reflected in the increasing number of DAC categories included.

\section{Livelihood data}

Information on livelihood conditions for each growing season were taken from FEWSNET's food security reports, starting from 2000 (FEWS NET 2018b). Data were extracted on a trimonthly basis for 2000-2016 and categorized by topics, growing season, and location (see Nilsson et al. 2019). For the Lac region, the FEWSNET reports were complemented by the annual reports from the Société de Développement du Lac (SODELAC 2014). The analytical potential of this database was however limited by the large spatial units used in the reports, as well as the inconsistent nature of the information, where the detail, focus, and style vary over time. Added to this, the reports are biased toward crises and events with high levels of food insecurity, with less reporting on factors driving crop production in food secure areas.

\section{Identifying drivers of gradual change}

\section{Demographics and agriculture}

The effects of demographic changes on agricultural variables were evaluated by regression-based statistical analyses. This statistical method was opted for to be able to quantify the effects of changes in the continuous demographic variables on the agricultural variables for specific periods. The effect of altered soil water availability on the agricultural variables was included by subtracting its effect on the response variables according to the methodology described in "Soil moisture" section and Nilsson et al. (2019). Differences in the agricultural sectors between the Sahelian and Soudanian zones were expected to be pronounced, so the regional comparisons were split between these two groups of regions. As this results in small observation sets (eight regions in the
Sahelian zone, five regions in the Soudanian zone), only generic relationships based on bivariate linear regressions were evaluated, which omits the effects of multivariate interactions, and the statistical relationships should thus only be seen as indicative. The significance levels of the linear regressions were estimated with a sieve based bootstrap method, by estimating the exceedance of the $t$-statistics for the linear slope coefficient from regressions on 1000 groups of simulated residuals to the original $t$-statistics. The residuals were simulated by fitting an autoregressive model, combined with the wild fixed-bootstrap regressor to account for potential heteroscedasticity in the residuals (Gonçalves and Kilian 2007; Lee 2011; Webb 2014).

\section{International aid and agriculture}

The effects of international aid on agricultural variables were also evaluated by regression-based statistical analyses. As data on international aid and agricultural variables were available for each year, regression analyses were run both on an annual level within each region, and over varying period lengths between the regions in each ecological zone. Previous studies have established that the effect of international aid on GDP growth generally is decreasingly positive (Ali and Isse 2005), which has also been seen for statistical models on the GDP in Chad (Juselius et al. 2014). Building on these studies, the annually based analysis was done with a lagged multivariate regressions analysis, by using the lagged logarithm of the amount of international aid over $0-5$ years on the agricultural variables each year, with significance level estimated based on the previously described bootstrap methodology.

To address the issues of unknown and varying time components in the effect of international aid, the annually based analysis within regions was complemented with a coarser analysis between regions at varying evaluation periods. While the annually based analysis is more detailed and has the potential to provide more policy relevant results, this latter inter-regional comparison can account for variations in the temporal effect of international aid by using different evaluation periods. Notable drawbacks are that the number of observations per period is limited by the number of regions, and that any statistically established relationship assumes that the effect of international aid per budget unit is equal between the evaluated regions. By evaluating the regional differences for all 1-27-year periods in 1990-2016, a large number of samples were created, with observations in each sample consisting of the regions in either the Sahelian or Soudanian zone.

\section{Identifying drivers of abrupt change}

Although factors of long-term changes can be established based on the statistical methods described for the demographic and international aid data, it does not answer how these effects 
Table 2 Link scoring system for causes of abrupt changes

\begin{tabular}{|c|c|c|c|}
\hline \multirow{2}{*}{$\begin{array}{l}\text { Link } \\
\text { score }\end{array}$} & \multirow[t]{2}{*}{ Description } & \multicolumn{2}{|l|}{ Examples } \\
\hline & & Positive & Negative \\
\hline 1 & $\begin{array}{l}\text { Abrupt change characteristic in the } \\
\text { wrong direction }\end{array}$ & - & - \\
\hline 2 & No link in the correct direction & - & - \\
\hline 3 & Weak link in the correct direction & $\begin{array}{l}\text { - Increased market prices* } \\
\text { - Increased production and food } \\
\text { security from previous year* }\end{array}$ & $\begin{array}{l}\text { - Decreased market prices* } \\
\text { - Decreased production and food security from previous year* }\end{array}$ \\
\hline 4 & $\begin{array}{l}\text { Strong link in the correct direction } \\
\text { without abrupt change characteristic }\end{array}$ & $\begin{array}{l}\text { - Increased rainfall } \\
\text { - Humanitarian aid, e.g., } \\
\text { subsidized seeds or food aid }\end{array}$ & $\begin{array}{l}\text { - Conflicts } \\
\text { - Pests } \\
\text { - Drought }\end{array}$ \\
\hline 5 & $\begin{array}{l}\text { Strong link in the right direction with } \\
\text { abrupt change characteristic }\end{array}$ & $\begin{array}{l}\text { - Farm-specific training } \\
\text { - Farm machinery } \\
\text { - Expanded market coverage } \\
\text { - Livelihood switches to a } \\
\quad \text { specific crop }\end{array}$ & $\begin{array}{l}\text { - Livelihood switches from a specific crop } \\
\text { - Production shocks leading to poverty traps, e.g., due to } \\
\text { conflicts or pests. Given the high poverty levels, positive } \\
\text { production shocks are not expected to leave lasting positive } \\
\text { effects }\end{array}$ \\
\hline
\end{tabular}

*The expected effects on regional crop production from variations in market prices and productive capacity from previous years are uncertain, as the household responses will vary according to their market dependencies

on the agricultural variables are realized in practice. This can be approached by analyzing the abrupt changes in agricultural production against the seasonal livelihood data provided in FEWSNET reports. A link scoring system was created to provide a consistent evaluation framework (Table 2), where scores of 5 were considered to be explanations for abrupt, while scores of 3 and 4 only provide explanations of why the agricultural variable in a given year deviated in the direction of the identified abrupt change. A prominent risk with this method is that of false positives, i.e., with enough diversity in the qualitative information source one can always find some description that corresponds to the evaluated statistical pattern of change.

\section{Results}

This section presents an overview of the datasets, the assessment of gradual and abrupt changes in the agricultural variables, as well as combined assessments of the influence of international aid, livelihood changes, soil water availability, and demographic changes for the agricultural variables in selected regions. Brief interpretations of the results as well as connections between the results are given in this section, while management implications and perspectives on improved research is provided in the "Discussion" section.

\section{Overview of datasets}

The relative change in agricultural output and total population per region for 1990-2016 are presented in Fig. 1a, joined with the agricultural and total population in Fig. $1 \mathrm{~b}$ for 1993, 2009, and 2014. Ratios of abrupt and gradual processes behind the growth in the agricultural variables are included, as identified by Nilsson and Uvo (2018). Figure 1a shows that most of the changes seen in the agricultural sector are driven by increases in the harvested area. Despite having one of the world's highest population growth, agricultural production is outgrowing population with considerable margins in almost all regions, which emphasizes the influence of factors beyond population driven demand and labor availability. A linear regression between the production growth rates and the production start levels in 1990 gives an $R^{2}$ of 0.05 , demonstrating that the agricultural growth rates in this period are independent from their initial conditions. Figure $1 \mathrm{~b}$ shows that the relative size of the agricultural population in relation to the total population is declining in all regions over the studied time period, and that the absolute size of the agricultural population has even declined in four of the 13 regions. $^{2}$ Moreover, the variations in population changes in Fig. $1 \mathrm{~b}$ illustrate the diversity in demographic profiles between the regions.

Figure 2a shows that international aid to Chad has increased tremendously over time, which can only be explained to a smaller degree by improvements in the reporting of international aid. The three escalating peaks of 2004, 2010, and 2012 are best understood as responses to the heightened humanitarian crises in Chad and its neighboring countries, such as Boko Haram-related conflicts in Nigeria, the civil war in the Central African Republic, and conflicts in Sudan, which affect the closest regions in Chad (Biltine, Ouaddai, Salamat, and Moyen Chari, in Fig. 2b). Besides Emergency Response, the other top DAC categories in ODA are, in descending order,

\footnotetext{
${ }^{2}$ Caution is warranted over the validity of the estimates from the 2014 survey, which only covered a sample rate of $9 \%$ of the household, contrary to $100 \%$ sample rates in 1993 and 2009.
} 

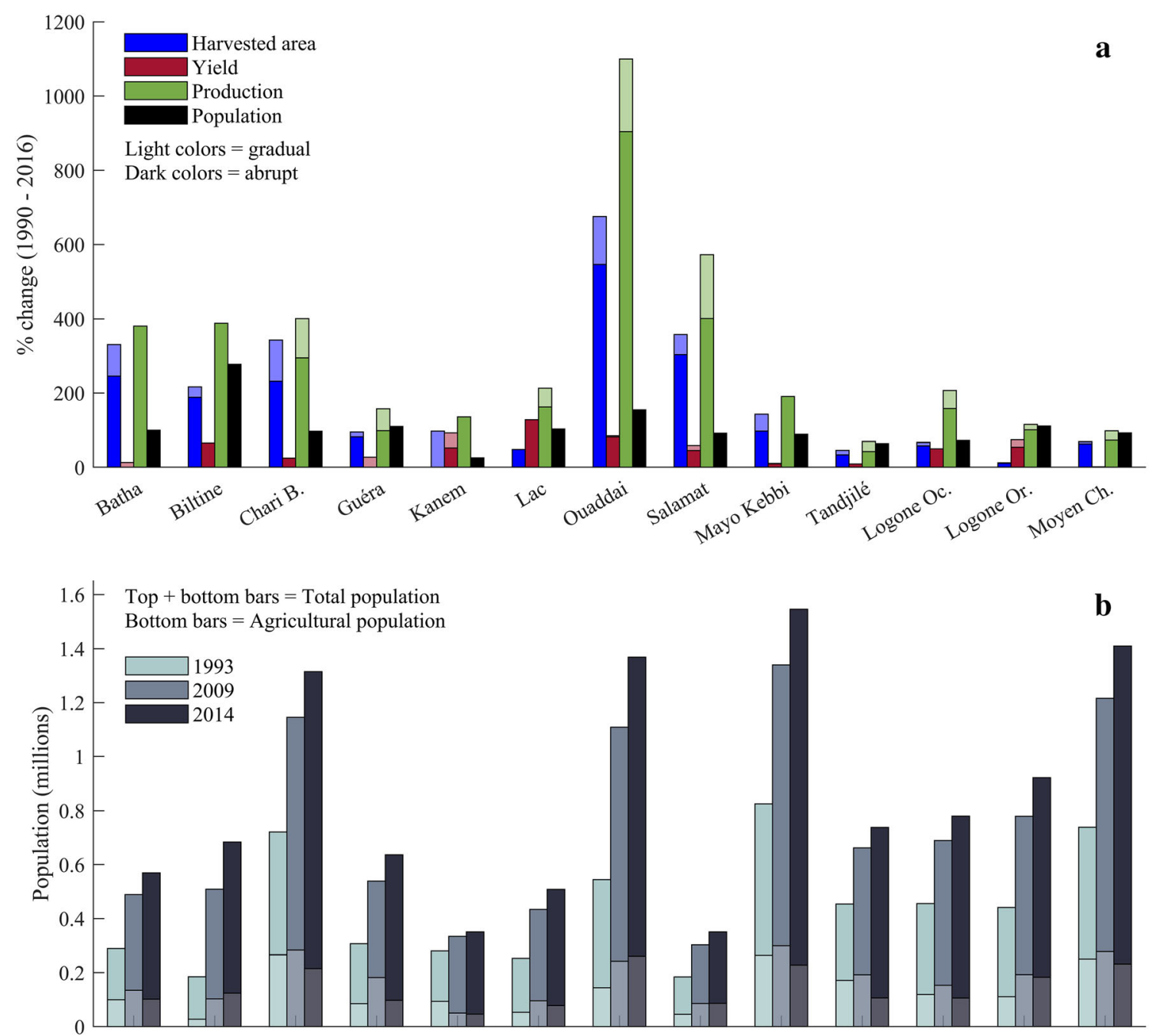

Fig. 1 (a) Agricultural \% change for 1990-2016 for harvested area, yield, and production per region, with attribution to abrupt and gradual processes according to Nilsson and Uvo (2018); and (b) total and agricultural

"Agriculture, Forestry, and Fishing," "Health," "Government and Civil Society," "Administrative Costs of Donors," and "Water Supply and Sanitation." With a ratio of region-specific international aid at 59\% (Fig. 2b), the location attribution methodology is sufficiently successful to allow for a comparison of the effects of international aid between the regions. The remaining $41 \%$ of the international aid with no specific location established is likely to be a mixture of international aid given to national ministries, and project entries that only have generic project descriptions, or lack descriptions completely.

\section{Gradual changes}

\section{Relationship between key demographic variables and agricultural change}

The associations between demographic and agricultural changes between the regions in the Sahelian and the population for 1993, 2009, and 2014. The data for the total population in 2016 (a) and 2014 (b) are extrapolated exponentially from the latest population census in 2009

Soudanian zones are presented in Table 3 . All crop categories are generally increasing for these time periods, which implies that a negative correlation to a demographic variable means that the agricultural growth decreases when the demographic variable grows, and not that the resulting agricultural growth is negative. Although the small sample sizes limit the possibilities for statistical significance (Sahelian zone $=8$, Soudanian zone $=5$ ), there are interesting associations in Table 3 between demographic and agricultural variables to interpret.

In both the Sahelian and Soudanian zones, there are several positive associations between growth rates in the agricultural variables and growth rates in total and agricultural population, which are in turn linearly correlated (Pearson correlation coefficient in the Sahelian zone $=0.92$, in the Soudanian zone $=$ 0.67). This is likely due to combinations of increased local demand for agricultural products and an increasing rural population engaging in agriculture following common 

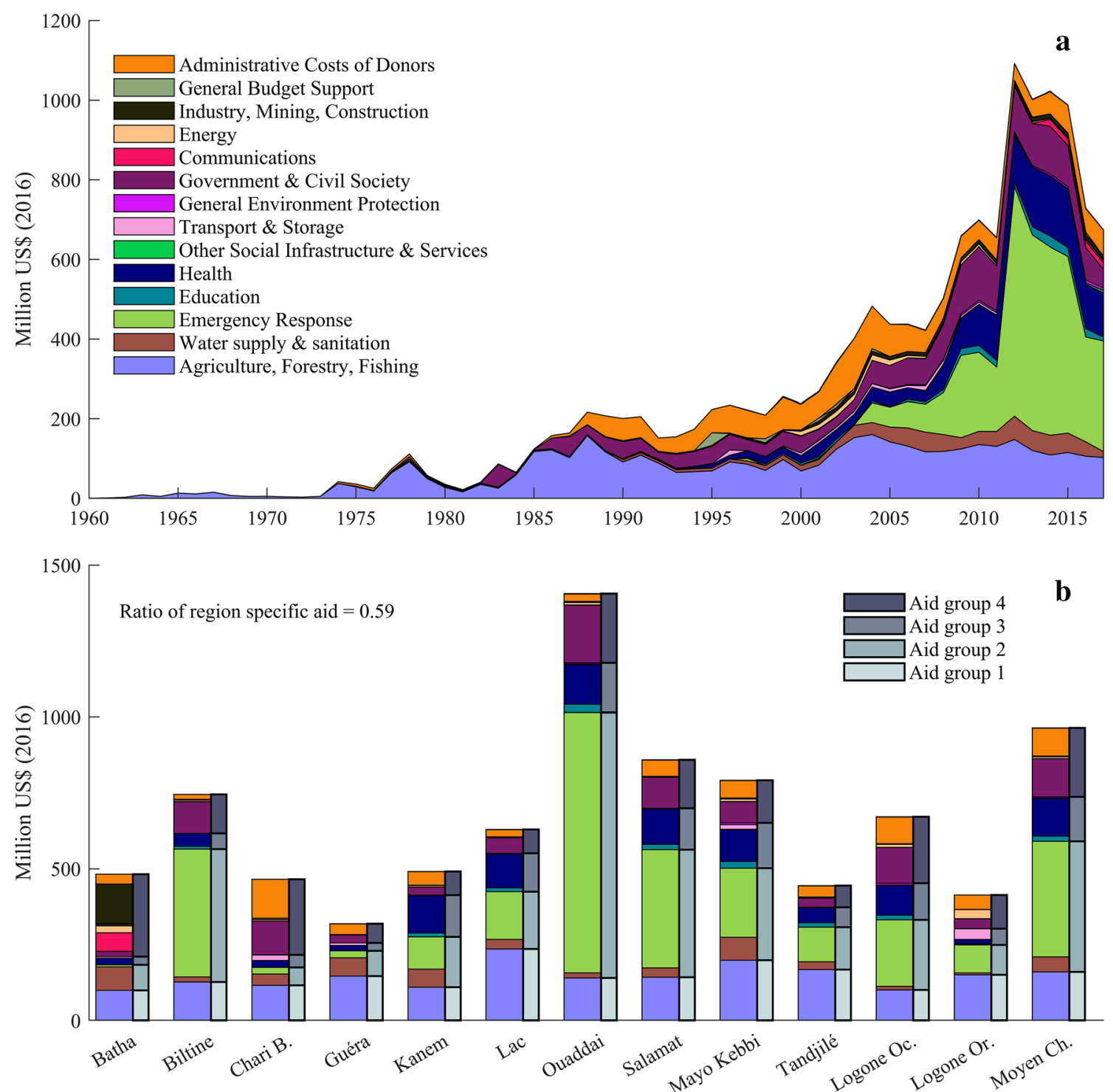

Fig. 2 (a) Gross ODA to Chad in 1960-2017 per DAC category, and (b) per region. Note that the aid groups in this figure are represented cumulatively (i.e., Aid group 2 are the first 2 categories)

livelihoods. Moreover, the $R^{2} \mathrm{~s}$ involving the agricultural population are generally decreasing over the analyzed time periods (1993-2009, 1993-2014, 2009-2014), which either implies a shift in these associations with growing population density or inaccurate estimates from the partial demographic census in 2014.

The lack of association between the agricultural variables and the total population in the Soudanian zone demonstrates that its agricultural systems respond to factors beyond the respective regions to a larger degree than in the Sahelian zone, either through sales to national or cross-border markets. While the agricultural population is positively correlated to both the harvested area and the yield in the Sahelian zone, in the Soudanian zone it is only linked to the yield, which reflects the Soudanian zone's more intensive farming practices (FEWS NET 2011; Republic of Chad 2009). Soudanian regions with higher growth rates in poor population are negatively correlated with growths in the harvested area, indicating that the growth in harvested area in the Soudanian zone partly is driven by economically potent groups, presumably through investment heavier practices than in the Sahelian zone. This can also be inferred from the negative correlations seen for the growths of both the total and agricultural population to the harvested area in the Soudanian zone. Additionally, the negative correlation between harvested area and income equality in the Soudanian zone can be due to a similar dynamic, namely that increasing income inequality reflects economic accumulation within top income cohorts, a process which in turn pushes agricultural intensification over extensification.

In contrast, a positive association is identified between growth in the poor population to the production in the Sahelian zone, which is likely realized through the expansions 
Table 3 Coefficients of determination $\left(R^{2}\right)$ from linear regressions between $\%$ change to key demographic and agricultural variables

\begin{tabular}{|c|c|c|c|c|c|c|}
\hline & \multicolumn{2}{|l|}{ Harvested area } & \multicolumn{2}{|l|}{ Yield } & \multicolumn{2}{|l|}{ Production } \\
\hline & Sahelian zone & Soudanian zone & Sahelian zone & Soudanian zone & Sahelian zone & Soudanian zone \\
\hline \multicolumn{7}{|l|}{ Total population } \\
\hline (1993-2009) & $0.43 * *$ & 0.01 & $0.63 * *$ & 0.02 & $0.2 * *$ & 0.03 \\
\hline \multicolumn{7}{|c|}{ Agricultural population } \\
\hline$(1993-2009)$ & $0.39 * *$ & 0.41 & $0.44 * *$ & $0.68^{*}$ & $0.20 * *$ & 0.04 \\
\hline (1993-2014) & $0.16^{*}$ & 0.07 & $0.54 * *$ & $0.45^{*}$ & $0.35 * *$ & 0.13 \\
\hline (2009-2014) & $\underline{0.10}$ & 0.21 & 0.17 & 0.09 & 0.16 & 0.03 \\
\hline \multicolumn{7}{|l|}{ Poor population } \\
\hline$(\%, 2003-2013)$ & 0.60 & $0.44 * *$ & 0.04 & 0.08 & $0.77 *$ & 0.00 \\
\hline \multicolumn{7}{|l|}{ Literate population } \\
\hline$(\%, 1993-2009)$ & 0.07 & 0.01 & $0.45^{* *}$ & 0.08 & 0.04 & 0.11 \\
\hline \multicolumn{7}{|l|}{ Mean income } \\
\hline$(\%, 2003-2011)$ & 0.00 & 0.08 & 0.01 & 0.23 & 0.06 & 0.00 \\
\hline \multicolumn{7}{|l|}{ Income inequality } \\
\hline$(\%, 2003-2011)$ & 0.05 & $0.31 *$ & 0.10 & 0.59 & 0.00 & 0.57 \\
\hline
\end{tabular}

${ }^{*} p \leq 0.05$ significance level, ${ }^{* *} p \leq 0.01$. Regressions with negative slope coefficients are underlined

of agricultural areas connected to growth in the rural poor population. Lastly, the growth in the ratio of literate population is strongly associated to growth in the yield in the Sahelian zone, which emphasizes the role of educational improvements in small-scaled farm management and intensified practices. Growth in the literate population is further strongly correlated to the total population (Pearson correlation coefficient $=0.77$ ) and the poor population $(0.74)$. The pronounced difference in association between the growth in literate and poor population to the yield thus indicates that increased literacy, and not increased poor population, takes part in driving the yield growth in the Sahelian zone. The lack of association between literacy and yield in the Soudanian zone is probably explained by its higher literacy rates, which in 2009 on average was $29 \%$ compared to the Sahelian average of $8 \%$ (INSEED 2012).

\section{Relationship between international aid and agricultural change}

From the annually based lagged multivariate regression between the logarithm of international aid in the four aid groups and agricultural growth (see "International aid data" section), only one region, Kanem, had any significant correlations established, which discards the validity of this method for these datasets. Turning instead to the inter-regional regression analysis over the full 1990-2016 period, interesting results emerge (Table 4). The effect of altered soil moisture conditions was included in this analysis by subtracting its estimated effects according to the method described in "Soil moisture" section. Variations in reporting of international aid over the studied period are expected to affect the regions equally and should therefore not affect the reliability of this analysis.

It is interesting to note that Aid group 1, which only focuses on agriculture (as well as forestry and fishing which are less common in Chad), has the weakest associations with all agricultural variables. Moreover, it is only for Aid group 4, including all types of international aid, that statistically significant associations to harvested area and production appear, and then only in the Sahelian zone (Table 4). For the yield, Aid groups $2-4$ produce significant associations in the Sahelian zone, with the strongest association between the yield and Aid group 3, which in addition to Aid group 2 includes General Environmental Protection, Transport \& Storage, Education, Health, and Other Social Infrastructure \& Services. That both education-related international aid and the rate of literate population (Table 3 ) are positively correlated to the yield in the Sahelian zone, and not in the Soudanian zone, is noteworthy. This relationship is further supported by the amount of education related international aid received in the Sahelian regions having a significant positive correlation to the growth in literate population (linear regression $R^{2}=$ $0.29, p=0.07$ ), while no significant association is detected for the Soudanian regions.

To give an estimate of the association between the amount of international aid received and agricultural growth over time, a more detailed review is conducted by looking at the variations in these associations over a large number of subperiods for each of the aid groups. The rates of significant associations $(p \leq 0.05)$ between the logarithm of international 
Table 4 Coefficients of determination $\left(R^{2}\right)$ from linear regressions between the logarithm of total aid per aid group and $\%$ growth in agricultural variables for 1990-2016

\begin{tabular}{|c|c|c|c|c|c|c|}
\hline & \multicolumn{2}{|c|}{ Harvested area $(\%)$} & \multicolumn{2}{|l|}{ Yield (\%) } & \multicolumn{2}{|l|}{ Production (\%) } \\
\hline & Sahelian zone & Soudanian zone & Sahelian zone & Soudanian zone & Sahelian zone & Soudanian zone \\
\hline Aid group 1 & 0.00 & 0.22 & 0.21 & 0.05 & 0.06 & 0.00 \\
\hline Aid group 2 & 0.34 & 0.47 & $0.30 *$ & 0.24 & 0.59 & 0.13 \\
\hline Aid group 3 & 0.28 & 0.52 & $0.38 * *$ & 0.23 & 0.52 & 0.19 \\
\hline Aid group 4 & $0.60 * *$ & 0.37 & $0.25 *$ & 0.12 & $0.78 * *$ & 0.22 \\
\hline
\end{tabular}

$* p \leq 0.05$ significance level, $* * p \leq 0.01$

aid and agricultural variables for the 351 possible periods (all periods at length 2-27 years for 1990-2016) per aid group were thus calculated to identify which aid group was the best predictor to changes in the agricultural variables (Table 5). Aid group 4 (including all types of international aid) is again the best predictor of change in the agricultural variables, which stresses the importance of understanding the agricultural sector as being intertwined with developments in society in general. The remarkably low rates of significant associations for the yield and production in the Soudanian zone point to a general decoupling of agricultural growth from the amount of international aid received, contrary to the Sahelian zone.

As the logarithmic relationship between international aid and agricultural growth varies over the evaluated periods and the significant regressions behind the results in Table 5, the best estimate of a consistent such relationship was taken as the mean of all the significant relationships together with its $95 \%$ confidence interval. Figure 3 presents this estimated effect of the total amount of international aid received per year on the annual agricultural growth rate for the Sahelian and Soudanian regions. As the only factors involved in these estimates are the total amount of international aid and the effects of soil water availability, the neglect of other positive drivers is bound to result in an overestimation of the effect of international aid. Also, as the estimated equations are taken as the best estimate from the full set of significant regressions, these results should mainly be read as indications of the relative influence of international aid on agricultural production between the regions and periods.
Despite the pronounced differences between the regions in production and international aid levels, the region-specific graphs in Fig. 3 show that these estimates generally align with the agricultural changes. The narrow ranges of the confidence intervals further show that these relationships are consistent over the full set of periods with significant regressions (Table 5). Overestimations are seen for Chari Baguirmi, Kanem, Lac, and Moyen Chari, which point to a general decoupling in agricultural growth from the amount of international aid received in these periods. As these estimates are based on the amount of international aid in all DAC categories (Aid group 4), this could be interpreted as international aid in periods of overestimation being directed toward non-agriculture-related sectors, or simply that it has been less effective than in the other regions. The equation estimates for the two zones are notably similar, and imply that positive annual agricultural growth effects from international aid are only detected on a regional level after approximately $\$ 5$ million per year and region in the Sahelian zone, and $\$ 9$ million in the Soudanian zone. Additionally, Fig. 3 shows that while the amplitudes of the variability in the soil water estimates from the international aid level are in the same range as the variability in the agricultural production, the year-to-year agreement is visibly low. Moreover, it shows that the estimated effects of long-term changes in soil water availability are minor in comparison to the estimated effects from

Table 5 Rate of periods* with significant associations

\begin{tabular}{|c|c|c|c|c|c|c|}
\hline & \multicolumn{2}{|l|}{ Harvested area } & \multicolumn{2}{|l|}{ Yield } & \multicolumn{2}{|l|}{ Production } \\
\hline & Sahelian zone & Soudanian zone & Sahelian zone & Soudanian zone & Sahelian zone & Soudanian zone \\
\hline Aid group 1 & 0.11 & 0.12 & 0.10 & 0.01 & 0.07 & 0.05 \\
\hline Aid group 2 & 0.14 & 0.29 & 0.21 & 0.00 & 0.23 & 0.05 \\
\hline Aid group 3 & 0.13 & 0.29 & 0.22 & 0.00 & 0.21 & 0.05 \\
\hline Aid group 4 & 0.25 & 0.26 & 0.12 & 0.00 & 0.32 & 0.08 \\
\hline
\end{tabular}

*Number of periods $=351$ 



$$
\begin{aligned}
& \text { Agr. }\left(\frac{\%}{\mathbf{y}}\right)=-\mathbf{1 2 . 1}+\mathbf{5 . 6} \times \log \left(\frac{\operatorname{Aid} \mathbf{M} \$}{\mathbf{y}}\right) \\
& \mathrm{CI}(\%)= \pm 13.7
\end{aligned}
$$

Fig. 3 Agricultural production and estimated agricultural trend levels due to international aid in 1993-2016, with estimated soil water effects, for the regions in the Sahelian zone (a) and the Soudanian zone (b)

international aid, that they generally have had a negative development in the Sahelian zone, and a positive development in the Soudanian zone. The most consistent deviation from the soil water estimate is displayed in Batha and Biltine, both in the northern part of the Sahelian zone.

\section{Abrupt changes}

While the estimates of the effects of international aid in Fig. 3 align well with the long-term production changes, marked deviations are noticed in several periods. To address this, potential causes for the full set of 45 abrupt changes in the 
Table 6 Summary of link scores and attribution factors behind the abrupt changes to harvested area

\begin{tabular}{|c|c|c|c|}
\hline Score & Occurrence & Positive factors & Negative factors \\
\hline 1 & $0(0 \%)$ & - & - \\
\hline 2 & $3(7 \%)$ & - & - \\
\hline 3 & $7(16 \%)$ & $\begin{array}{l}\text { - High market prices (6) } \\
\text { - Refugee communities increasing the amount of harvested area (2) } \\
\text { - Humanitarian assistance programs (2) } \\
\text { - Unverified crop switch from cotton (2) } \\
\text { - Delayed start of rainy season could have led farmer to focus on recession farming }\end{array}$ & - \\
\hline 4 & $8(18 \%)$ & $\begin{array}{l}\text { - High market prices (4) } \\
\text { - Good rains (4) } \\
\text { - Flooding increased area for recession farming (3) } \\
\text { - Government assistance (2) } \\
\text { - Humanitarian assistance programs } \\
\text { - Increased demand due to oil project } \\
\text { - Government investments during election year } \\
\text { - Potential cereal crop switch } \\
\text { - Farm seeds }\end{array}$ & - \\
\hline 5 & $27(60 \%)$ & $\begin{array}{l}\text { - High market prices (16) } \\
\text { - Farm inputs (9) } \\
\text { - Crop switch from cotton (7) } \\
\text { - Farm trucks/tractors (7) } \\
\text { - Community assistance for refugees (5) } \\
\text { - Good rains (5) } \\
\text { - Cereal crop switch (4) } \\
\text { - Farm seeds (3) } \\
\text { - Farm training (4) } \\
\text { - Floods (2) } \\
\text { - Lifting of trade embargo with Sudan (2) } \\
\text { - Livelihood switch from charcoal production } \\
\text { - Livelihood switch from pastoralism } \\
\text { - Increased demand from the Sahelian zone due to closed border with Libya } \\
\text { - Humanitarian aid }\end{array}$ & $\begin{array}{l}\text { - Large number of refugees (1) } \\
\text { - Cereal deficits (1) } \\
\text { - Delayed rains (1) } \\
\text { - Floods (1) }\end{array}$ \\
\hline
\end{tabular}

Factors with abrupt change characteristics are in bold, and factor occurrences in parentheses

harvested area, as identified by the statistical analysis in Nilsson and Uvo (2018), based on information in food security reports for the respective growing seasons, are presented in the Appendix. The summary of link scores (see "Identifying drivers of abrupt change" section) and attributed factors for these changes to the harvested area is presented in Table 6 . According to the applied scoring system, $60 \%$ of the abrupt changes to the harvested area have been successfully linked to potential causes (link score 5), 18\% were only linked to conducive productive conditions without lasting effect for the occurring year (link score 4), while the remaining 23\% (link score 1-3) represents abrupt changes with no causal indications established. The various types of farm support are the most prevalent factors linked to the positive abrupt changes, which were reported in 17 out of the 45 abrupt changes. Several geopolitical aspects have also been identified, such as the effects of refugees and trade with neighboring countries.

The summary of link scores and attributed factors for the abrupt changes in the yield is presented in Table 7, while the full range of 24 abrupt changes are given attributions in the Appendix. Slightly lower than for the harvested area, the rate of link score 5 is $46 \%$, and again with a high prevalence of farm support and trade with neighboring countries.

\section{Combined evaluation}

Figure 4 presents three examples where the agricultural production, international aid relationships, effects from soil water availability, and livelihood factors are combined. In the "Aid alignment" example (Fig. 4a, Logone Oriental), the only noteworthy deviation from the estimated effect of international aid is the increased production in 2003 to 2007, which in 2003 is attributed to a resumption of trade with the Central African Republic, assistance provided to refugees, and favorable growing conditions. The estimated effect of soil water availability fluctuates but with a stable pattern, and only occasionally matches the variability in the agricultural production, indicating that omitted drivers with high variability are influential. In the "Aid overestimation" example (Fig. 4b, Chari Baguirmi), the estimated effects from international aid diverge from the agricultural trends after a drop in the production in 2012. This indicates that international aid to the rural sector 
Table 7 Summary of link scores and attribution factors behind the abrupt changes to the yield

\begin{tabular}{|c|c|c|c|}
\hline Score & Occurrence & Positive factors & Negative factors \\
\hline 1 & $0(0 \%)$ & - & - \\
\hline 2 & $3(13 \%)$ & - & - \\
\hline \multirow[t]{2}{*}{3} & $1(4 \%)$ & Government investments during election year & \\
\hline & $9(38 \%)$ & $\begin{array}{l}\text { Floods } \\
\text { Food aid (5) }\end{array}$ & \\
\hline \multirow{5}{*}{4} & & Good rain (4) & \\
\hline & & High market prices (4) & \\
\hline & & Potential cereal crop switch (2) & \\
\hline & & Reduced harvested area & \\
\hline & & Farmer mobilization & \\
\hline \multirow[t]{9}{*}{5} & $11(46 \%)$ & Farm inputs (9) & \\
\hline & & Farm trucks/tractors (4) & \\
\hline & & Humanitarian aid (4) & \\
\hline & & High market prices (2) & \\
\hline & & Good rains (3) & \\
\hline & & Farm training & \\
\hline & & Increased market opportunities with Sudan & \\
\hline & & Increased market opportunities with CAR & \\
\hline & & Government awarding lands to settlers & \\
\hline
\end{tabular}

Factors with abrupt change characteristics are in bold could have turned toward non-cereal crops in this period, or that the events around 2012 resulted in a decrease in the agricultural growth rate in the following years. In the "Mid-period deviation" example (Fig. 4c, Salamat), agricultural production display marked increases without being matched by an increasing amount of international aid around 2003-2006. The pronounced jump in 2003 have been linked to an exceptional flooding event, which both expanded the amount of area available for flood recession sorghum that year, and presumably sustained that production level for the coming years.

\section{Discussion}

The results have showed that the connection between increased agricultural population and production is not consistent across regions and time periods. As a recognized core driver of agricultural change across Sub-Saharan Africa, the effects of rising population density are partly mediated by land constraints and migration responses (Jayne et al. 2014; van Vliet et al. 2013), which varies notably between the regions in Chad. This is a likely explanation of the differences in demographic relationships between the Sahelian and Soudanian zones, where growth rates of both total and agricultural population in the Sahelian regions are positively correlated with extensification and intensification, while only so to intensification in the Soudanian regions. The comparison of changes in income-related demographics further points to agricultural change being driven by commercial actors to a larger degree in the Soudanian zone. One main implication of these relationships between demography and the agricultural sector is that food security monitoring must recognize the local and seasonal effects on food demand and production stemming from population growth and movements. By showing that demographic effects on the agricultural sector are distinguishable on a regional level, this study has provided a strong case to collect data on both demography and crop production on subregional levels, to be able to identify how the need for production assistance and food security interventions vary in space and time. This would provide an improved detail and efficiency for agricultural development and food security programs.

Although changes to soil water availability have been linked to the interannual variability in crop production in previous studies (Nilsson et al. 2019), they were found to be largely decoupled from the long-term trajectories in agricultural production. The occurrence and extent of floods were on the other hand on several occasions connected to both production anomalies and adaptation strategies, which point to the importance of understanding local adaptation strategies to altered hydrological regimes. Data on soil fertility were omitted from the analysis, but are generally seen to be declining over time in response to intensified cultivation across Sub-Saharan Africa (Jayne et al. 2014). One key implication of this is that it is not changes in crop water availability due to rainfall variability that has driven the notable long-term increases in 
Fig. 4 Combined evaluation for examples of "Aid alignment" (a),

"Aid overestimation" (b), and

"Mid-period deviation" (c)
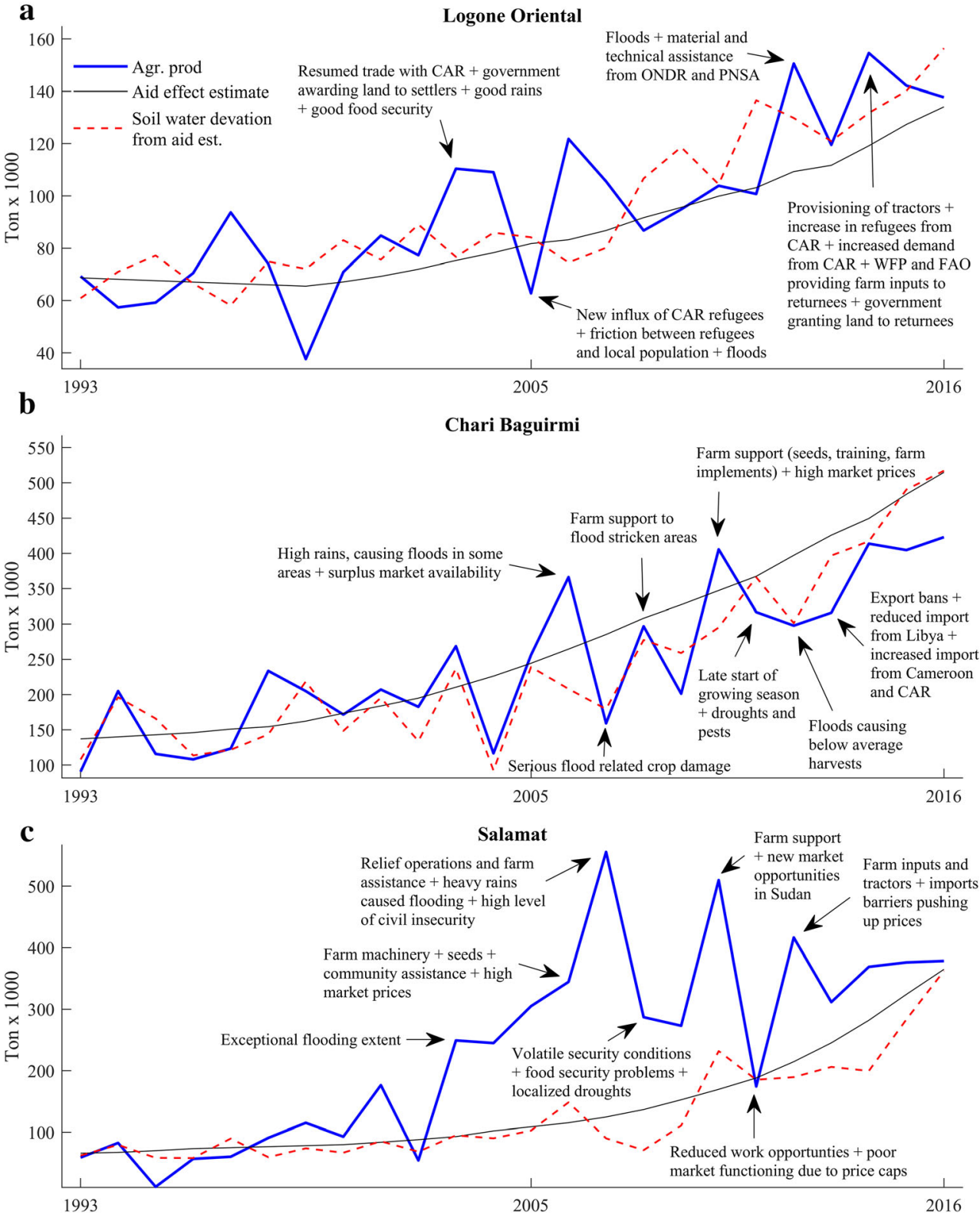

agricultural production in Chad over the past 30 years. This emphasizes the role of anthropogenic over environmental factors in the agricultural systems in Chad, and provides added justification to both amplify such interventions and to target them in research programs.

This study has moreover evaluated the effect of some of these anthropogenic factors. The results show that both the amounts of international aid received in the respective regions and the livelihood descriptions taken from FEWSNET's food security reports give credible, yet partial, descriptions of the drivers of agricultural change in Chad. Despite being applied to regions with large differences in levels of agricultural production and amount of international aid received, the estimated relationships to international aid for the regions show considerable agreement. The positive association between international aid and crop production is stronger in the Sahelian zone than in the Soudanian zone, which is likely a result of the lower levels of agricultural specialization and economic development in the former. The results further show that international aid constituted by the full set of DAC categories are better predictors of agricultural growth than DAC categories focused on the agricultural sector, indicating a high level of connectedness between the agricultural and other socio-economic sectors. Education-related international aid was connected to both literacy rates and yield improvements in the Sahelian zone, while no such effects were distinguished in the Soudanian zone. One possible explanation for these differences is that the Soudanian zone has had higher literacy rates over the studied period, giving educational efforts in the Sahelian zone a relatively stronger effect. Although the 
relevance of international aid for the rural sector in Chad has been known and studied previously (IRAM-ADE 2016), this is the first time the amounts of international aid have been disaggregated on a subnational level and evaluated against the changes to the agricultural production. Except for the extensive time required to collect and structure the agricultural and international aid data, this is promising for similar applications in other countries in the Sahel. That the effects of international aid on the agricultural production are statistically detectable on a regional level, in combination with the finding that long-term production trajectories largely are decoupled from variations in rainfall, shows that international aid has been one of the strongest factors in increasing agricultural production. The identification of the positive relationship between education focused international aid and agricultural production in the Sahelian zone is especially important, which should be used to augment this type of aid.

Despite the general agreements seen over the full periods of estimated effects from international aid and the agricultural growth, periods of marked deviations point to additional complexities. Application of the livelihood information was able to address some of these deviations, and overall provided reliable explanations for $50 \%$ of the abrupt changes in the production series, albeit in broad terms. With a rate of abrupt changes to the agricultural production at around $80 \%$ (Nilsson and Uvo 2018), the set of factors identified with high reliability in Tables 6 and 7 can thus be seen as key drivers of agricultural changes in Chad. More specifically, they point to the relevance of various kinds of farm support from the public sector and development organizations, as well as how trade networks, market dynamics, and crop switches play key roles in driving the nonlinear production dynamics. This provides a strong argument for the need of farm support programs, as well as a justification to target the evaluation and improvement of such programs through research projects. The identified effects of local market prices and access to new markets in Sudan mean that communication improvements and regional trade are bound to further drive expansions and specializations in the agricultural systems. At the same time, the lack of detail in the identified livelihood factors point to the limits of these datasets and methods, which need further specification to be applicable in quantitative evaluations. Moreover, due to the small sample sizes, mainly in the demographic data and the interregional analysis of international aid, several key relationships are bound to have been missed, and the established relationships could benefit from additional precision and certainty.

The findings from this study clearly show that the patterns and drivers of change in agricultural systems in the Sahel must be analyzed on subnational levels, and in connection to their geopolitical context. To achieve this, the research environment in Chad and the Sahel would benefit from increased accessibility to already collected datasets. This would also serve as a useful complement to the many monitoring programs with a strong focus on remote sensing products (Fritz et al. 2019). Specific examples of such data include locationspecific and quality-verified data on international aid, location-specific and categorized livelihood data, and soil water products adapted to local growing conditions. Several monitoring functions are already in place to address these issues. The food security reports and general monitoring by FEWSNET, WFP, FAO, and various NGOs, as well as the evaluations reports for development projects, provide a wealth of livelihood related data for the agricultural sector. Improving the detail and accessibility in these reports, together with additional collaboration between researchers and practitioners, is a cost-efficient approach to enhance a data-driven research environment in Chad and the Sahel.

\section{Conclusion}

This study has identified a range of factors that drove the abrupt and gradual changes in the agricultural production in Chad over the past 30 years. Changes in the total and agricultural population, literacy improvements, international aid, governmental farm support, and access to markets have all been identified as regional agricultural drivers. On the other hand, changes in soil moisture were found to be largely decoupled from the long-term changes in crop production. The main implication of the role of population changes is that food security monitoring must recognize the local and seasonal effects on food demand and production due to population increase and regional movements. The findings further provide justifications to intensify and expand farm support programs for an increased and stabilized crop production. General international aid was found to be a better predictor of agricultural growth than sector-specific international aid, which shows that the agricultural sector is intertwined with general societal development. Moreover, both changes to literacy rates and education focused international aid were found to be strongly associated with agricultural growth in the Sahelian zone, which strengthens the justification for an educationally driven development policy. As variations in local market prices and access to new markets in Sudan were identified as influential to the agricultural production, improved communications and facilitation of regional trade can be targeted for management of the agricultural sector. Through a combination of novel datasets on hydrology, food security, and international aid, together with qualitative and quantitative methods, this study presents a framework for improved evaluation of the drivers behind subnational crop production on multiannual and decadal time scales, with broad applicability in agricultural systems in the Sahel. 
Acknowledgments The authors would like to thank the Chadian institutions that provided data used in this study, most notably Direction de la Production et des Statistique Agricoles (DPSA), Institut National de la Statistique, des Études Économiques et Démographiques (INSEED), and Direction des Ressources en Eau et de la Météorologie (DREM), all based in N'Djamena. Funding was provided by the Swedish Research Council, the Crafoord Foundation, and the Division of Water Resources Engineering at Lund University.

Funding information Open access funding provided by Lund University.

\section{Compliance with ethical standards}

Conflict of interest The authors declare that they have no conflict of interest.

Open Access This article is licensed under a Creative Commons Attribution 4.0 International License, which permits use, sharing, adaptation, distribution and reproduction in any medium or format, as long as you give appropriate credit to the original author(s) and the source, provide a link to the Creative Commons licence, and indicate if changes were made. The images or other third party material in this article are included in the article's Creative Commons licence, unless indicated otherwise in a credit line to the material. If material is not included in the article's Creative Commons licence and your intended use is not permitted by statutory regulation or exceeds the permitted use, you will need to obtain permission directly from the copyright holder. To view a copy of this licence, visit http://creativecommons.org/licenses/by/4.0/.

\section{References}

Abro ZA, Alemu BA, Hanjra MA (2014) Policies for agricultural productivity growth and poverty reduction in rural Ethiopia. World Dev 59:461-474. https://doi.org/10.1016/j.worlddev.2014.01.033

Ali AM, Isse HS (2005) An empirical analysis of the effect of aid on growth. Int Adv Econ Res 11(1):1-11. https://doi.org/10.1007/ s11294-004-7177-6

Allen RG, Pereira LS, Raes D, Smith M (1998) Crop Evapotranspiration (FAO Irrigation and Drainage Paper No. 56). Irrigation and Drainage (Vol. 300)

Andrews DWK (1993) Tests for parameter instability and structural change with unknown change point. Econometrica 61(4):821-856. https://doi.org/10.2307/2951764

Bachewe FN, Berhane G, Minten B, Taffesse AS (2015) Agricultural Growth in Ethiopia (2004-2014): Evidence and Drivers (no. 81). Ethiopia Strategy Support Program

Binswanger-Mkhize H, McCalla AF (2010) Chapter 70 the changing context and prospects for agricultural and rural development in Africa. In: Pingali P, Evenson R (eds) Handbook of agricultural economics, vol 4, 1st edn. Elsevier B.V, Oxford, pp 3571-3712. https://doi.org/10.1016/S1574-0072(09)04070-5

CILSS (2018) Comité permanent Inter-états de Lutte contre la Secheresse dans le Sahel. Retrieved October 10, 2018, from http://www.cilss. int/

Doorenbos J, Kassam AH (1979) Yield response to water. FAO Irrigation and Drainage Paper No. 33

DPSA (2017) Production agricole 1990-2016. Direction de la Production et des Statistique Agricoles, Government of Chad, N'Djamena

Epule ET, Bryant CR (2015) Drivers of arable production stagnation and policies to combat stagnation based on a systematic analysis of drivers and agents of arable production in Cameroon. Land Use
Policy 42:664-672. https://doi.org/10.1016/j.landusepol.2014.09. 018

FAO (2016) Food Price Monitoring and Analysis Tool. Retrieved May 15, 2016, from http://www.fao.org/giews/pricetool/. Food and Agricultural Organization of the United Nations

FAO (2018a) FAOSTAT. Retrieved October 20, 2018, from http://faostat. fao.org/. Food and Agricultural Organization of the United Nations

FAO (2018b) GIEWS - Global Information and Early Warning System. Retrieved October 10, 2018, from http://www.fao.org/giews/en/. Food and Agricultural Organization of the United Nations

FAO, \& AfDB (2015) Agricultural growth in West Africa - market and policy drivers. (F. Hollinger \& J. M. Staatz, Eds.). Rome: FAO \& AfDB. Food and Agricultural Organization of the United Nations \& African Development Bank

FEWS NET (2011) Chad rapid livelihood zone profiles - a special report by the Famine Early Warning Systems Network (FEWS NET). Famine Early Warning Systems Network, N'Djamena

FEWS NET (2015) CHAD food security outlook January through June 2015 food security starting to deteriorate in parts of Chad, (June). Famine Early Warning Systems Network, N'Djamena

FEWS NET (2018a) West Africa. Retrieved October 20, 2018, from http://fews.net/west-africa. Famine early warning systems network

FEWS NET (2018b) Publication Archive. Retrieved may 15, 2017. URL https://www.fews.net/archive. Famine Early Warning Systems Network

Food Security Cluster (2018). Food Security Cluster. Retrieved October 10, 2018, from https://fscluster.org/

Fritz S, See L, Carlos J, Bayas L, Waldner F, Jacques D et al (2019) A comparison of global agricultural monitoring systems and current gaps. Agric Syst 168(December 2017):258-272. https://doi.org/10. 1016/j.agsy.2018.05.010

Fuglie KO, Rada NE (2013) Resources, policies, and agricultural productivity in Sub-Saharan Africa (ERR No. 145). Washington, DC

Gonçalves S, Kilian L (2007) Asymptotic and bootstrap inference for AR $(\infty)$ processes with conditional heteroskedasticity. Econ Rev 26(6): 609-641. https://doi.org/10.1080/07474930701624462

Goodman S, Benyishay A, Runfola D (2016) Overview of the geo framework. AidData, Institute for the Theory and Practice of International Relations

Herdt RW (2010) Chapter 63 Development aid and agriculture. In: Pingali P, Evenson R (eds) Handbook of agricultural economics, vol 4, 1st edn. Elsevier B.V., Oxford. https://doi.org/10.1016/ S1574-0072(09)04063-8

Houssou N, Chapoto A (2014) The changing landscape of agriculture in Ghana: drivers of farm mechanization and its impacts on cropland expansion and intensification. IFPRI discussion paper 01392. International Food Policy Research Institute

IATI (2018a) D-portal search. Retrieved June 20, 2018, from http://www. d-portal.org/ctrack.html\#view=search. International aid transparency initiative

IATI (2018b) IATI Datastore. Retrieved May 25, 2018, from https:// iatistandard.org/en/using-data/IATI-tools-and-resources/IATIdatastore/. International Aid Transparency Initiative

IFAD (2011) Food security project in northern Guéra region. International Fund for Agricultural Development

IMF (2013) Chad: staff-monitored program. International Monetary Fund

IMF (2015) Chad - Poverty reduction strategy paper-Joint staff advisory note on the 2013 monitoring reports of the National Development Plan 2013-2015. International Monetary Fund, Washington

INSEED (1993) Recensement général de la population et de l'habitat 1993. N'Djamena: Institut National de la Statistique, des Etudes Economiques et Demographiques

INSEED (2006) Deuxième Enquête sur la Consommation et le Secteur Informel au Tchad (ECOSIT 2). N'Djamena: Institut National de la Statistique, des Etudes Economiques et Demographiques 
INSEED (2008) Tableau des codes des circonstritions. N'Djamena: Institut National de la Statistique, des Etudes Economiques et Demographiques

INSEED (2012) Deuxième Recensement Général de la Population et de l'Habitat 2009-Resultat Globaux Definitifs. N'Djamena: Institut National de la Statistique, des Etudes Economiques et Demographiques

INSEED (2013) Troisième Enquête sur la Consommation et le Secteur Informel au Tchad (ECOSIT3). N'Djamena: Institut National de la Statistique, des Etudes Economiques et Demographiques

INSEED, Ministère de la Santé Publique, ICF International (2016) Enquête Démographique et de Santé et à Indicateurs Multiples (EDS-MICS 2014-2015). Rockville, Maryland, USA

IRAM-ADE (2016). Evaluation de la coopération de 1' Union Européenne avec la République du Tchad 2008-2014. Paris: Institut de Recherches et d'Applications des Méthodes de développement

Jayne TS, Chamberlin J, Headey DD (2014) Land pressures, the evolution of farming systems, and development strategies in Africa: a synthesis. Food Policy 48:1-17. https://doi.org/10.1016/j.foodpol. 2014.05.014

Josephson AL, Ricker-Gilbert J, Florax RJGM (2014) How does population density influence agricultural intensification and productivity? Evidence from Ethiopia. Food Policy 48:142-152. https://doi.org/ 10.1016/j.foodpol.2014.03.004

Juselius K, Møller NF, Tarp F (2014) The long-run impact of foreign aid in 36 African countries: insights from multivariate time series analysis. Oxf Bull Econ Stat 76(2):153-184. https://doi.org/10.1111/ obes. 12012

Lee DJ (2011) Bootstrap Tests for Structural Breaks When the Regressors and Error Term are Nonstationary (Department of Economics Working Paper Series no. 2011-05). Storrs

MaxMind (2018) Free World Cities Database. Retrieved June 25, 2018, from https://www.maxmind.com/en/free-world-cities-database

Ministry of Agriculture and Irrigation (2013) Plan quinquennal de développment de l'agriculture au Tchad. N'Djamena

Muyanga M, Jayne TS (2014) Effects of rising rural population density on smallholder agriculture in Kenya. Food Policy 48:98-113. https://doi.org/10.1016/j.foodpol.2014.03.001

Nilsson E, Uvo CB (2018) Nonlinear dynamics in agricultural systems in Chad. Afr Geogr Rev. https://doi.org/10.1080/19376812.2018. 1485585

Nilsson E, Uvo CB, Becker P, Persson M (2019) Drivers of regional crop variability in Chad. J Arid Environ. https://doi.org/10.1016/j. jaridenv.2019.104081

Nin Pratt A (2015) Agricultural intensification in Africa: a regional analysis (no. 01433). IFPRI Discussion Paper

Nin-Pratt A, McBride L (2014) Agricultural intensification in Ghana: evaluating the optimist's case for a green revolution. Food Policy 48:153-167. https://doi.org/10.1016/j.foodpol.2014.05.004

OECD (2018a) Purpose Codes: sector classification. Organisation for Economic Co-operation and Development. Retrieved from http:// www.oecd.org/dac/stats/purposecodessectorclassification.htm. Accessed 20 May 2018

Ouedraogo I, Mbow C, Balinga M, Neufeldt H (2015) Transitions in land use architecture under multiple human driving forces in a semi-arid zone. Land 4(3):560-577. https://doi.org/10.3390/land4030560

Ouédraogo M, Zougmoré R, Moussa AS, Partey ST, Thornton PK, Kristjanson $P$ et al (2017) Markets and climate are driving rapid change in farming practices in Savannah West Africa. Reg Environ Chang 17(2):437-449. https://doi.org/10.1007/s10113016-1029-9

Republic of Chad (2009) Enquête de Sécurité Alimentaire et de Vulnérabilité Structurelle. N'Djamena

République du Tchad (2003) Schéma directeur de l'eau et de l'assainissement du Tchad 2003-2020 (SDEA). N'Djamena

République du Tchad (2014) Plan National d'Investissement du Secteur Rural du Tchad (2014-2020). Version 2, 26 May 2014. N'Djamena

République du Tchad (2017) Plan National de Développement 2017 2021. N'Djamena

Snorek J, Renaud FG, Kloos J (2014) Divergent adaptation to climate variability: a case study of pastoral and agricultural societies in Niger. Glob Environ Chang 29:371-386. https://doi.org/10.1016/j. gloenvcha.2014.06.014

SODELAC (2014) Rapports Annuels 1988-2012. N’Djamena. Société de Développement du Lac

Steduto P, Hsiao TC, Fereres E, Raes D (2012) Crop yield response to water (no. 66). FAO Irrigation and Drainage Paper. Rome

Traore SB, Ali A, Tinni SH, Samake M, Garba I, Maigari I et al (2014) AGRHYMET: a drought monitoring and capacity building center in the West Africa region. Weather Clim Extremes 3:22-30. https:// doi.org/10.1016/j.wace.2014.03.008

UNHCR (2018a) Factsheet Chad August 2018. N'Djamena: United Nations High Commissioner for Refugees

UNHCR (2018b) Population statistics. Retrieved June 25, 2018, from http://popstats.unhcr.org/en/time_series. United Nations High Commissioner for Refugees

Valbuena D, Groot JCJ, Mukalama J, Gérard B, Tittonell P (2015) Improving rural livelihoods as a "moving target": trajectories of change in smallholder farming systems of Western Kenya. Reg Environ Chang 15(7):1395-1407. https://doi.org/10.1007/s10113014-0702-0

van Vliet N, Reenberg A, Rasmussen LV (2013) Scientific documentation of crop land changes in the Sahel: a half empty box of knowledge to support policy? J Arid Environ 95:1-13. https://doi.org/10. 1016/j.jaridenv.2013.03.010

Webb MD (2014) Reworking Wild Bootstrap Based Inference for Clustered Errors (Queen's Economics Department Working Paper No. 1315). Kingston

WFP (2013) Enquête Nationale de la Sécurité Alimentaire des ménages ruraux (ENSA). N'Djamena: World Food Programme

Wood SA, Jina AS, Jain M, Kristjanson P, DeFries RS (2014) Smallholder farmer cropping decisions related to climate variability across multiple regions. Glob Environ Chang 25(1):163-172. https://doi.org/10.1016/j.gloenvcha.2013.12.011

World Bank (2014) Public expenditure review in the agricultural, rural development, and food security sector

World Bank (2018a) Project and operations. Retrieved June 1, 2018, from http://projects.worldbank.org/?lang=en

World Bank (2018b) World Development Indicators. Retrieved October 1, 2018, from http://data.worldbank.org/data-catalog/worlddevelopment-indicators

Publisher's note Springer Nature remains neutral with regard to jurisdictional claims in published maps and institutional affiliations. 